\title{
Development of a SCAR Marker to Track Canola Resistance Against Blackleg Caused by Leptosphaeria maculans Pathogenicity Group 3
}

\author{
M. Dusabenyagasani and W. G. D. Fernando, Department of Plant Science, University of Manitoba, Winnipeg, \\ MB, R3T 2N2, Canada
}

\begin{abstract}
Dusabenyagasani, M., and Fernando, W. G. D. 2008. Development of a SCAR marker to track canola resistance against blackleg caused by Leptosphaeria maculans pathogenicity group 3 . Plant Dis. 92:903-908.

Blackleg of rapeseed and canola (Brassica napus) is caused by various pathogenicity groups (PG) of Leptosphaeria maculans. The disease occurring in the Canadian prairies for the last two decades was caused by PG2 and was controlled by host resistance. PG3 and PG4 isolates have been found recently in Canada, but there is no resistance available against these pathogenicity groups in commercial Canadian varieties. This study sought to identify canola cultivars that could be used as sources of resistance to PG3 and to develop molecular markers for markerassisted selection. Resistance to PG3 specifically was found in B. napus 'Dunkeld' and 'Quinta', while $B$. juncea 'Cutlass' and 'Domo' proved to be resistant to PG2, PG3, and PG4. A set of $F_{2}$ progeny of 'Westar' (susceptible) $\times$ 'Dunkeld' was used to identify genetic markers linked to PG3 resistance. These markers were physically located on a BAC clone from B. rapa subsp. pekinensis containing a homolog to a serine threonine 20 (ste20)-like kinase in Arabidopsis thaliana. Thus, we have developed a sequence characterized amplified region (SCAR) marker available for marker-assisted selection in breeding canola for resistance against blackleg caused by L. maculans PG3. This work has received a provisional patent (serial \# 60/977,933 - Oct. 5, 2007).
\end{abstract}

Additional keyword: SRAP

Blackleg (Phoma stem canker) of rapeseed and canola (Brassica napus L.) is a disease with a worldwide distribution caused by a complex of fungal plant pathogens belonging to Leptosphaeria maculans (Desm.) Ces. \& Not., anamorph Phoma lingam (Tode ex Fr.) Desm. Members of this species historically were divided into two pathotype groups, A and B (also A and NA groups, or Tox ${ }^{+}$and $\operatorname{Tox}^{0}$ groups), based on characters such as virulence, restriction fragment length polymorphism (RFLP) markers, and secretion of the phytotoxin sirodesmin into culture media $(48,49)$. Group A isolates are highly virulent and cause the damaging stem canker, while B group isolates are weakly virulent (59). Since group B isolates are morphologically different from and cannot sexually cross with group A isolates, they have been recently classified as a new species, L. biglobosa R.A. Shoemaker \& H. Brun (53). Group A isolates are distributed worldwide and cause significant losses in Australia, North America, and Europe (56). They have been subdivided

Corresponding author: Dilantha W. G. Fernando E-mail: D_Fernando@umanitoba.ca

Accepted for publication 15 January 2008.

doi:10.1094/PDIS-92-6-0903

(C) 2008 The American Phytopathological Society into pathogenicity groups (PG) 2, 3, 4, and $\mathrm{T}$ according to differential disease reactions on a set of $B$. napus cultivars with different resistance genes $(23,24,36,45)$. The subspecies structure of $L$. maculans is made even more complex by the fact that each of the four pathogenicity groups also comprises different races as revealed by analysis conducted with two differential sets (7).

Although restricted to the crucifers, $L$. maculans can infect various species under field and laboratory conditions (10,27). The host and the pathogen establish typical gene-for-gene interactions $(20,44,57)$. The outcome of the host infection is dependent on the presence of a major resistance gene in the host and a corresponding avirulence gene in the pathogen (4-6). Resistance genes have been traced in various Brassica species such as $B$. juncea, B. napus, $B$. rapa, and $B$. nigra $(15,16,42,51,52,54,60)$. Selection for blackleg resistance relies on cotyledon and adult stage resistance (47). Several authors have reported a significant correlation between resistance in cotyledons and adult plants $(8,24,26,35,39)$. Loci controlling cotyledon resistance as well as field resistance against $L$. maculans have been mapped to the N7 linkage group of the A genome in various $B$. napus genotypes $(18,20,33,34,43,46)$. Molecular markers associated with Brassica resistance against blackleg caused by PG2 and useful for maker-assisted selection have also been reported (3).
Blackleg of canola, which had been prevalent in the Canadian prairies for the last two decades, was caused by L. maculans PG2 and is well controlled by resistance. In 2002 and 2004, PG3 and PG4 isolates of $L$. maculans were discovered in Manitoba $(13,19)$. Since then, PG3 and PG4 also have been found in Alberta, North Dakota (USA), and more regions in Manitoba $(11,14)$. These new strains of $L$. maculans pose a serious threat to the Prairie canola industry because varieties currently grown are not resistant against them. The objectives of this study were to search for sources of resistance against blackleg of canola caused by L. maculans PG3 and to develop molecular markers for resistance-assisted selection.

\section{MATERIALS AND METHODS}

Search for sources of resistance. Ten entries from the University of Manitoba canola and Brassica germplasm bank were screened for resistance against isolates of L. maculans PG2, PG3, and PG4 from our laboratory fungal collection. They were preselected based on their descriptions in terms of resistance against blackleg with a bias toward $B$. napus genotypes from Europe and Australia where PG3 and PG4 had been previously reported (58). Differential canola cultivars Westar, Glacier, and Quinta were used as references $(23,36)$. Cultivars screened for resistance included B. napus 'Crésor', 'Dunkeld', 'Oscar', 'Rainbow', and 'Surpass 400', as well as B. juncea 'Cutlass' and 'Domo'. The cultivars were evaluated in a completely randomized experiment in the growth chamber with three replicate flats of each genotype per pathogen isolate. Genotypes were grown from seed (one per $6 \times 6 \times 7$ $\mathrm{cm}$ flat cell) in a soilless mix (Metromix, W.R. Grace and Co. Ltd., Ajax, Ont.). Seedlings were watered daily and kept under day and night temperatures of $21^{\circ} \mathrm{C}$ and $18^{\circ} \mathrm{C}$, respectively, and a $16-\mathrm{h}$ photoperiod. Seven days after seeding, eight fully expanding cotyledons were wounded on each lobe with a needle and inoculated with $10 \mu \mathrm{l}$ of spore suspension onto the wound. The inoculated cotyledons were allowed to dry at room temperature for at least $12 \mathrm{~h}$ before the next watering. Disease symptoms were rated 12 days after inoculation using a scale of 0 to $9(14,57)$ : 0 , no darkening around the wounds; 1 , limited blackening around the wound with a lesion diameter of 0.5 to $1.5 \mathrm{~mm}$, a faint 
chlorotic halo may be present, sporulation absent; 3 , dark necrotic lesions, a chlorotic halo of 1.5 to $3.0 \mathrm{~mm}$ in diameter may be present, sporulation absent; 5, lesions 3 to $5 \mathrm{~mm}$ in diameter and sharply delimited by a dark necrotic margin, may show graygreen tissue collapse, sporulation absent; 7 , gray-green tissue collapse, lesion 3 to 5 $\mathrm{mm}$ in diameter, sharply delimited by a nondarkened margin; 9, rapid tissue collapse at about 10 days accompanied by profuse sporulation in large lesions, more than $5 \mathrm{~mm}$ diameter, with a diffuse margin.

Mapping populations. Based on results from the resistance screening experiment, B. napus cultivar Dunkeld was used as a resistant parent in reciprocal crosses with the susceptible cultivar Westar. $F_{1}$ progeny from a 'Westar' female parent were evaluated for cotyledon resistance and selfpollinated for the production of $F_{2}$ progeny. Segregation of resistance against blackleg caused by L. maculans PG3 in the $\mathrm{F}_{2}$ generation was analyzed at the cotyledon stage, with 'Westar', 'Glacier', and 'Quinta' being included as references. Progeny that exhibited a severity rating of 5 or less on the 0 to 9 rating scale were considered resistant, while those with a higher score were considered susceptible.

DNA isolation and SRAP assays. Leaf and stem tissues from $340 \mathrm{~F}_{2}$ progeny were collected, freeze dried, ground, and used for genomic DNA isolation with a salt buffer based extraction protocol (1). Bulked segregant analysis (BSA, 37) was used together with sequence-related amplified polymorphisms (SRAP, 28) to search for markers polymorphic among the progeny and to identify those linked to canola resistance against L. maculans PG3 from 'Dunkeld'. A 22 sample set of genomic DNA from 'Westar' and 'Dunkeld' parents, 10 susceptible progeny, and 10 resistant progeny, along with two bulk samples, one from resistant and the other from suscepti- ble progeny, were used for screening 180 primer combinations. Ten primer sets that had amplified markers that were polymorphic between parents and among the progeny samples were used to analyze marker segregation within a 92-progeny mapping population. These primer sets are: $\mathrm{BG}_{16} /$ $\mathrm{ODD}_{3}, \mathrm{PM}_{111} / \mathrm{ODD}_{3}, \mathrm{BG}_{18} / \mathrm{ODD}_{20}, \mathrm{BG}_{20} /$ $\mathrm{SA}_{12}, \quad \mathrm{EM}_{2} / \mathrm{ME}_{2}, \quad \mathrm{ME}_{2} / \mathrm{DC}_{1}, \quad \mathrm{Na}_{12} \mathrm{~A}_{02} \mathrm{~F} /$ $\mathrm{Na}_{12} \mathrm{~A}_{02} \mathrm{R}, \mathrm{NA}_{12} \mathrm{D}_{04} \mathrm{~F} / \mathrm{NA}_{12} \mathrm{D}_{04} \mathrm{R}, \mathrm{Na}_{12} \mathrm{~F}_{12} \mathrm{~F} /$ $\mathrm{Na}_{12} \mathrm{~F}_{12} \mathrm{R}$, and $\mathrm{NGA}_{111} \mathrm{~F} / \mathrm{NGA}_{111} \mathrm{R}$ (Table 1). The segregation of two SRAP markers amplified by $\mathrm{Na}_{12} \mathrm{~A}_{02} \mathrm{~F} / \mathrm{Na}_{12} \mathrm{~A}_{02} \mathrm{R}$ primer set that were linked to resistance from 'Dunkeld' was confirmed in an additional 248 progeny sample set. Polymerase chain reaction (PCR) amplification reactions were performed in a $13-\mu \mathrm{l}$ reaction volume containing $15 \mathrm{ng}$ of template DNA, $0.4 \mu \mathrm{M}$ for each of two primers, 0.75 units of Taq polymerase (Fisher brand), $100 \mathrm{mM}$ Tris$\mathrm{HCl}(\mathrm{pH} 8.0), 500 \mathrm{mM} \mathrm{KCl}, 1.5 \mathrm{mM}$ $\mathrm{MgCl}_{2}$, and $0.1 \mathrm{mM}$ each of dNTPs. PCR amplification was run in a programmable thermal controller (Eppendorf MasterCycler Gradient, Eppendorf Canada Ltd., Mississauga, $\mathrm{ON})$. The first five cycles were run at $94^{\circ} \mathrm{C}$ for $1 \mathrm{~min}, 35^{\circ} \mathrm{C}$ for $50 \mathrm{~s}$, and $72^{\circ} \mathrm{C}$ for $1 \mathrm{~min}$ for denaturing, annealing, and extension, respectively. Then the remainder of the amplification was 36 cycles at $94^{\circ} \mathrm{C}$ for $50 \mathrm{~s}, 50^{\circ} \mathrm{C}$ for $50 \mathrm{~s}$, and $72^{\circ} \mathrm{C}$ for $1 \mathrm{~min}$. PCR products were separated by electrophoresis using a denaturing $5 \%$ polyacrylamide gel containing $7.5 \mathrm{M}$ urea. Gels were then silver stained with the Promega kit (Promega, Madison, WI, USA) according to the manufacturer's specifications. PCR assays were replicated once in order to confirm observed markers. The presence and absence of all fragments between molecular sizes of 50 and 500 base pairs (bp) were scored for each sample. Bands larger than 500 bp or less than $50 \mathrm{bp}$ were not scored because of insufficient resolution.

Table 1. Characteristics of primers used in this study

\begin{tabular}{lll}
\hline Primer name & Primer sequence $\left(5^{\prime}\right.$-3') & Source \\
\hline $\mathrm{BG}_{16}$ & TGATACCACTTGCGATACCA & G. Li \\
$\mathrm{BG}_{18}$ & GCAAGTCTCTCAGGTTATTC & $\mathrm{G} . \mathrm{Li}$ \\
$\mathrm{BG}_{20}$ & TCCTCTCCACTTTTGTCTC & $\mathrm{G}$. Li \\
$\mathrm{DC}_{1}$ & TAAACAATGGCTACTCAAG & G. Li \\
$\mathrm{EM}_{2}$ & GACTGCGTACGAATTCTG C & G. Li \\
$\mathrm{ME}_{2}$ & TGAGTCCAAACCGGAGC & G. Li \\
$\mathrm{Na}_{12} \mathrm{~A}_{02} \mathrm{~F}$ & AGCCTTGTTGCTTTCAACG & M. Trick \\
$\mathrm{Na}_{12} \mathrm{~A}_{02} \mathrm{R}$ & AGTGAATCGATGATCTCGCC & M. Trick \\
$\mathrm{Na}_{12} \mathrm{D}_{04} \mathrm{~F}$ & ACGGAGTGATGATGGGTCTC & M. Trick \\
$\mathrm{Na}_{12} \mathrm{D}_{04} \mathrm{R}$ & CCTCAATGAAACTGAAATATGTGTG & M. Trick \\
$\mathrm{Na}_{12} \mathrm{~F}_{12} \mathrm{~F}$ & CGTTCTCACCTCCGATAAGC & M. Trick \\
$\mathrm{Na}_{12} \mathrm{~F}_{12} \mathrm{R}$ & TCCGATGTAGAATCAGCAGC & M. Trick \\
$\mathrm{NGA}_{111} \mathrm{~F}$ & TGTTTTTTAGGACAAATGGCG & M. Trick \\
$\mathrm{NGA}_{111} \mathrm{R}$ & CTCCAGTTGGAAGCTAAAGGG & M. Trick \\
$\mathrm{ODD}_{3}$ & CCAAAACCTAAAACCAGGA & G. Li \\
$\mathrm{PM}_{111}$ & CTTTAGCAGCATTGTTACCA & G. Li \\
$\mathrm{SA}_{12}$ & TTCTAGGTAATCCAACAACA & G. Li \\
$\mathrm{BN}_{204 \mathrm{~F}}$ & GGTGCAAACGATGTATTCAAGA & This study \\
BN204R & CGTTTGTAAAACCGACCTTCA & This study \\
\hline
\end{tabular}

${ }^{\mathrm{a}} \mathrm{G}$. Li, University of Manitoba, Winnipeg, Manitoba, Canada.

${ }^{\mathrm{b}}$ M. Trick, BrassicaDB, John Innes Centre, Norwich, UK.

DNA sequencing and SCAR development. DNA bands of SRAP markers linked to resistance were collected from polyacrylamide gels, ground in $50 \mu \mathrm{l}$ of Tris EDTA, and incubated overnight at $4{ }^{\circ} \mathrm{C}$ in order to isolate DNA fragments. These fragments were used as template for PCR assays with the corresponding original SRAP primers. The PCR mixture composition used was similar to the one used in the SRAP assays except that cycling protocol was as follows: initial denaturation at $95^{\circ} \mathrm{C}$ for $5 \mathrm{~min}$; 35 cycles at $94^{\circ} \mathrm{C}$ for $30 \mathrm{~s}, 55^{\circ} \mathrm{C}$ for $20 \mathrm{~s}$, and $72^{\circ} \mathrm{C}$ for $1 \mathrm{~min}$; and a final DNA extension at $72^{\circ} \mathrm{C}$ for $6 \mathrm{~min}$. PCR products were purified using the Qiaquick PCR purification kit according to the producer specifications (Qiagen Inc., Mississauga, ON, Canada). Purified PCR products were sent for sequencing at Macrogen DNA Sequencing Service (Macrogen USA, Rockville, MD). The software ClustalX (55) was used for sequence alignment, and sequence alignments were edited with the Genedoc software (40). Similarity search with public library sequences was performed with BLASTn and BLASTx (2). A GenBank library sequence with a genomic region similar to our query was used to design new primers in order to develop sequence characterized amplified region (SCAR) markers linked to resistance in 'Dunkeld' against L. maculans PG3. These new primers were used to amplify genomic DNA from 'Westar' and 'Dunkeld'. The segregation of polymorphic markers was then analyzed with the 22-progeny sample set used for screening of SRAP primer combinations. Primer sets with markers that segregated as expected were used in analyzing the 92-progeny sample set for linkage mapping. The markers were later confirmed using the additional 248-progeny sample set.

Data analysis. Analysis of variance was performed on data from the search for sources of resistance experiment, and disease severity means were compared using Tukey's test. In the analysis of $F_{2}$ progeny from crossing 'Westar' with 'Dunkeld', chi-square test was run with MS Excel software to verify if segregation ratios of the resistance trait and molecular markers fit Mendelian ratios. Linkage analysis was performed with MapMaker Exp 3.0 computer program $(25,29)$ in order to identify molecular markers linked to the 'Dunkeld' resistance gene against blackleg caused by L. maculans PG3.

\section{RESULTS}

Sources of resistance. Statistical analysis revealed significant differences between Brassica genotypes as to their response to blackleg caused by $L$. maculans PG2, PG3, and PG4 (Fig. 1). Genotypes with a disease rating of 5 or less on a 0 to 9 scale were considered resistant, and those with a higher disease rating were susceptible (57). We found resistance against PG3 
in the Australian spring canola cultivar Dunkeld comparable to that of the winter cultivar Quinta, which is used as a differential in L. maculans pathogenicity group testing and known to carry cotyledon stage resistance genes against $L$. maculans PG2 and PG3. B. juncea cultivars Cutlass and Domo exhibited resistance against PG2, PG3, and PG4.

Segregation of resistance. Tests of 340 $\mathrm{F}_{2}$ 'Westar' $\times$ 'Dunkeld' progeny for response to PG3 revealed that 94 progeny were susceptible and 246 were resistant. Disease symptom ratings, on a 0 to 9 scale, ranged from 1 to 5 for resistant progeny, with an overall average rating of 2 , while the rating for all susceptible progeny was 9 (Fig. 2). According to chi-square analysis $\left(\chi^{2}=0.96\right)$, the segregation ratio of the resistance against $L$. maculans PG3 within $\mathrm{F}_{2}$ 'Westar' $\times$ 'Dunkeld' progeny was not significantly different from $3: 1$, which was consistent with a single dominant gene model.

Molecular markers. Bulked segregant analysis (BSA) used together with the SRAP methods allowed selection of 10 primer pairs (Table 1) from 180 primer combinations that produced polymorphic markers between parents and within progeny. Fifty-two polymorphic markers within $92 \mathrm{~F}_{2}$ 'Westar' $x$ 'Dunkeld' progeny were obtained using these 10 primer combinations. The segregation of four SRAP markers, including two from each of the primer combinations $\mathrm{Na}_{12} \mathrm{~A}_{02} \mathrm{~F} / \mathrm{Na}_{12} \mathrm{~A}_{02} \mathrm{R}$ and $\mathrm{BG}_{20} / \mathrm{SA}_{12}$, was consistent with the resistance segregation within the 92 tested progeny. The two markers from the first primer combination were 200 and $190 \mathrm{bp}$, and the markers from the last primer pair were 480 and 475 bp (Fig. 3).
Sequence results from the two $\mathrm{NA}_{12} \mathrm{~A}_{02}$ markers showed that they are from $\mathrm{CT}$ simple sequence repeat (SSR) regions and that two CT units differentiate 'Westar' from 'Dunkeld' with 17 and 19 repeats, respectively. BLASTn analysis revealed that this sequence has $96 \%$ homology (evalue $=1 \mathrm{e}^{-27}$ ) with a region of the Brassica rapa subsp. pekinensis BAC clone KBr0334I14 (GenBank accession number AC189311.1). BLASTx analysis of a $10 \mathrm{~kb}$ sequence flanking the $B$. rapa subsp. pekinensis homolog to the $\mathrm{NA}_{12} \mathrm{~A}_{02-200}$ marker identified a region with $92 \%$ amino acid similarity with an Arabidopsis thaliana serine threonine 20 (ste-20) pro- tein kinase $\left(\mathrm{e}\right.$-value $\left.=4 \mathrm{e}^{-173}\right)$. Primers BN204F and BN204R (Table 1) were designed from that clone sequence and provided the SCAR marker BN204 that is also linked to the cultivar Dunkeld resistance against $L$. maculans. The segregation ratio of the BN204 marker within the $\mathrm{F}_{2}$ generation of 'Westar' $\times$ 'Dunkeld' was consistent with a single dominant gene model and also allowed differentiation of homozygotic from heterozygotic resistant progeny (Fig. 4). Linkage analysis identified a linkage group on which the 'Dunkeld' resistance gene against $L$. maculans PG3 ( $\mathrm{Rpg}_{3}$ Dun) was closely linked to the BN204 SCAR marker and four SRAP

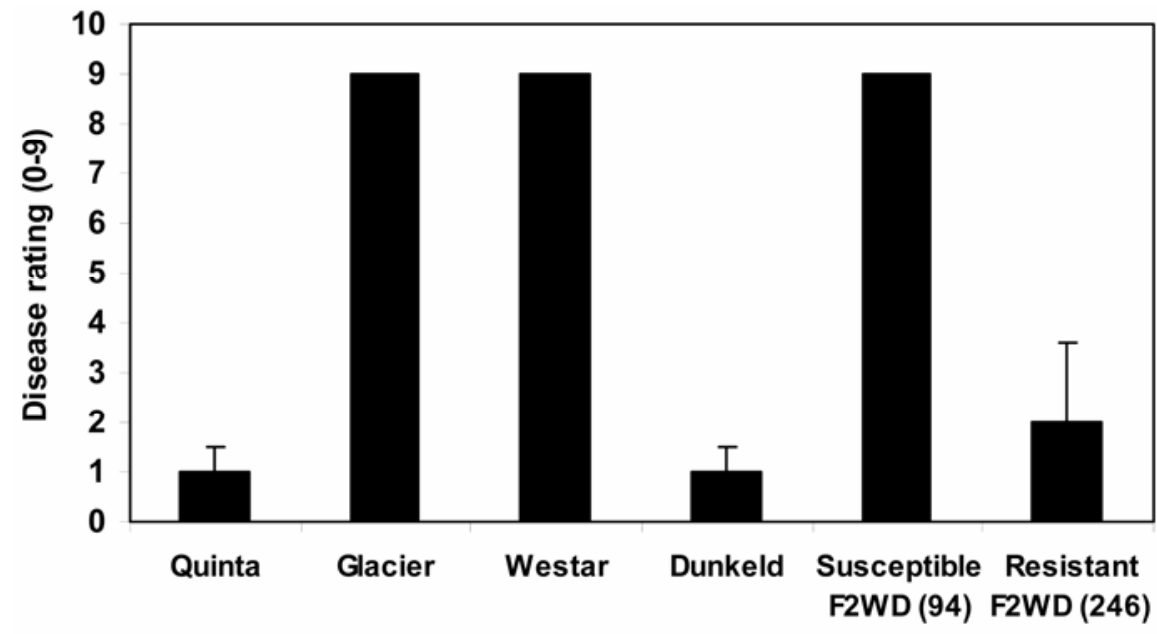

Brassica cultivars and progeny

Fig. 2. Segregation of resistance against Leptosphaeria maculans PG3 in $F_{2}$ 'Westar' $\times$ 'Dunkeld' progeny. Cultivars Glacier and Quinta were used as references. The disease ratings for 'Glacier', 'Quinta', and the parents 'Westar' and 'Dunkeld' are mean values from 12 seedlings. Disease ratings for $F_{2}$ 'Westar' $\times$ 'Dunkeld' progeny $\left(\mathrm{F}_{2} \mathrm{WD}\right)$ are average values from 94 susceptible progeny and 246 resistant ones.

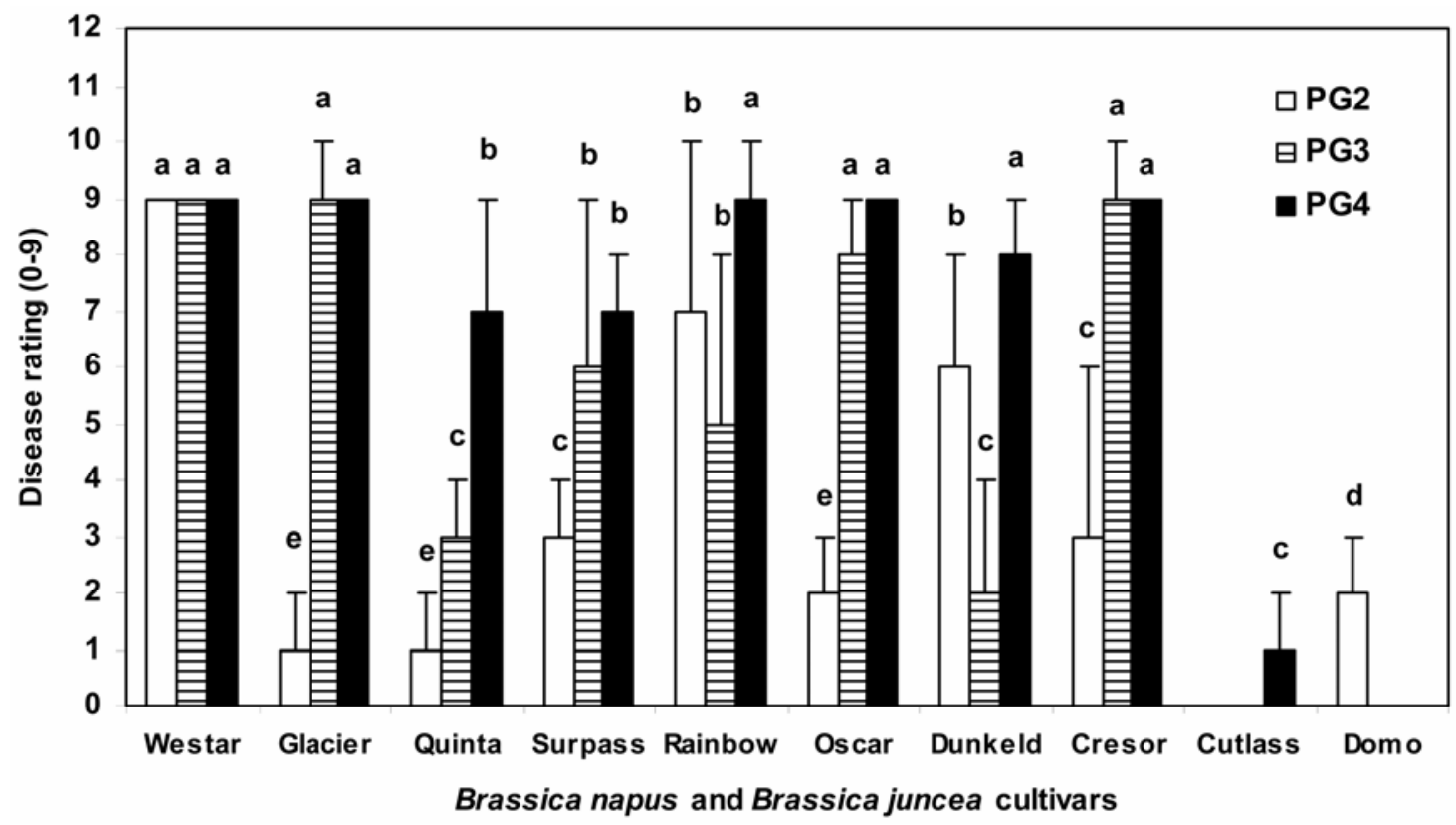

Fig. 1. Response of Brassica napus cultivars (Westar, Glacier, Quinta, Surpass 400, Rainbow, Oscar, Dunkeld, and Crésor) and B. juncea cultivars (Cutlass, Domo) to blackleg caused by Leptosphaeria maculans PG2, PG3, and PG4. Disease ratings for each cultivar are mean values from three replicate pots. Error bars on histograms represent standard deviation values. Letters above bars indicate statistical differences $(P=0.05)$ according to Tukey's test. 
markers (Fig. 5). Three additional SRAP markers including two from $\mathrm{BG}_{20} / \mathrm{SA}_{12}$ and one from $\mathrm{BG}_{18} / \mathrm{ODD}_{20}$ were located at 11.3 and $16.4 \mathrm{cM}$, respectively, from each side of the core region with the resistance gene. Twelve progeny were recombinant for resistance and the molecular markers analyzed in 340 progeny, the SRAP marker $\mathrm{NA}_{12} \mathrm{~A}_{02-200}$ and the SCAR marker BN204 (data not shown). Such a number was not significant because the calculated $\chi^{2}$ values of $1.56,0.06$, and 0.25 for the segregation

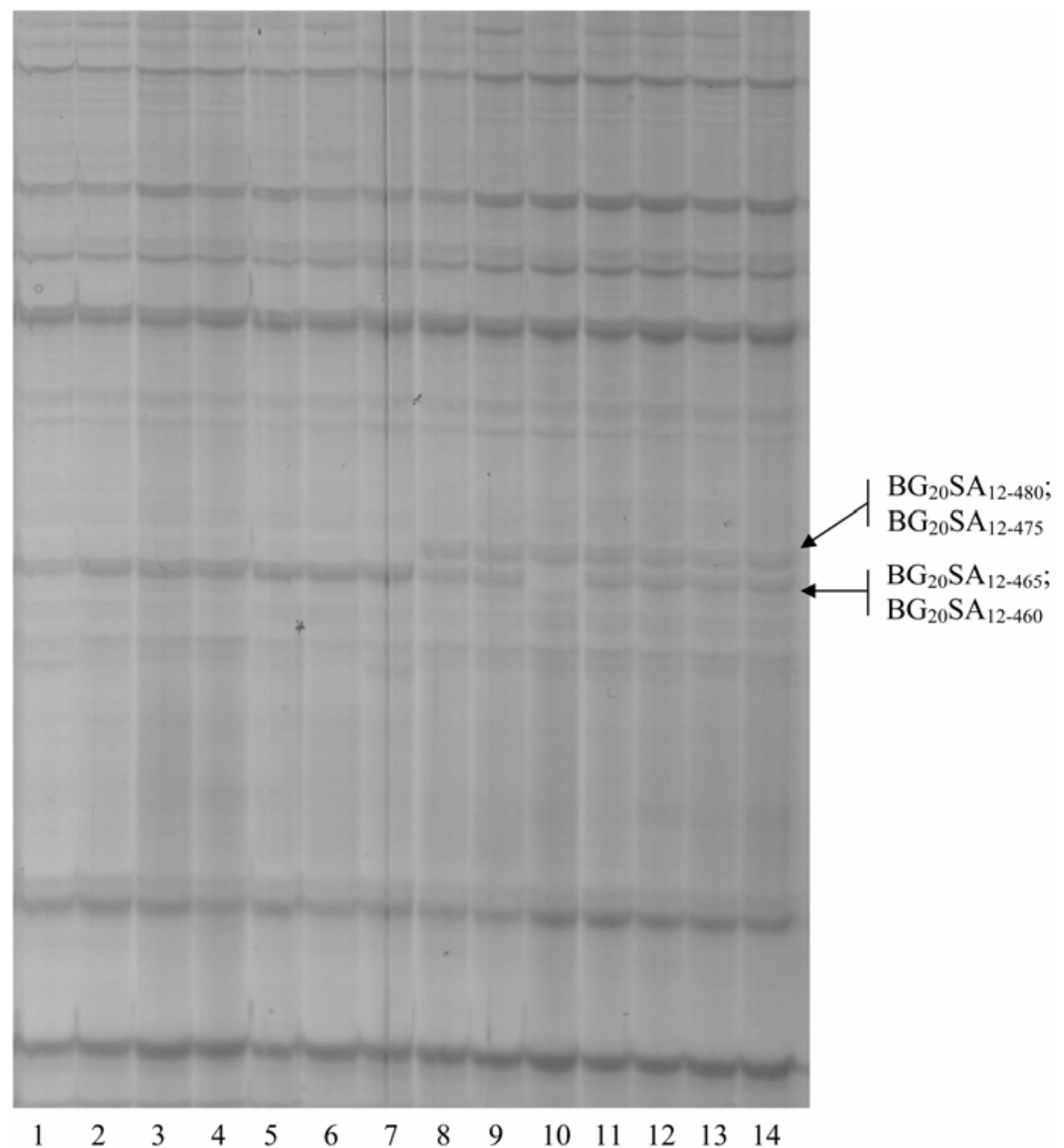

Fig. 3. Segregation of sequence-related amplified polymorphism (SRAP) markers linked to resistance against Leptosphaeria maculans in $\mathrm{F}_{2}$ 'Westar' $\times$ 'Dunkeld' progeny. Lanes 1 to 7: susceptible progeny, 8 to 14: resistant progeny. The four markers shown on the picture segregated within $92 \mathrm{~F}_{2}$ 'Westar' $\times$ 'Dunkeld' progeny in a ratio not significantly different from 3:1. Markers $\mathrm{BG}_{20} \mathrm{SA}_{12-480}$ and $\mathrm{BG}_{20} \mathrm{SA}_{12-475}$ were absent in all susceptible progeny (lanes 1 to 7 ) and present in all resistant ones (lanes 8 to 14). Markers $\mathrm{BG}_{20} \mathrm{SA}_{12-465}$ and $\mathrm{BG}_{20} \mathrm{SA}_{12-460}$ were present in 67 progeny, including all the 23 susceptible ones, and absent in the remaining 25 resistant ones, such as in lane 10.

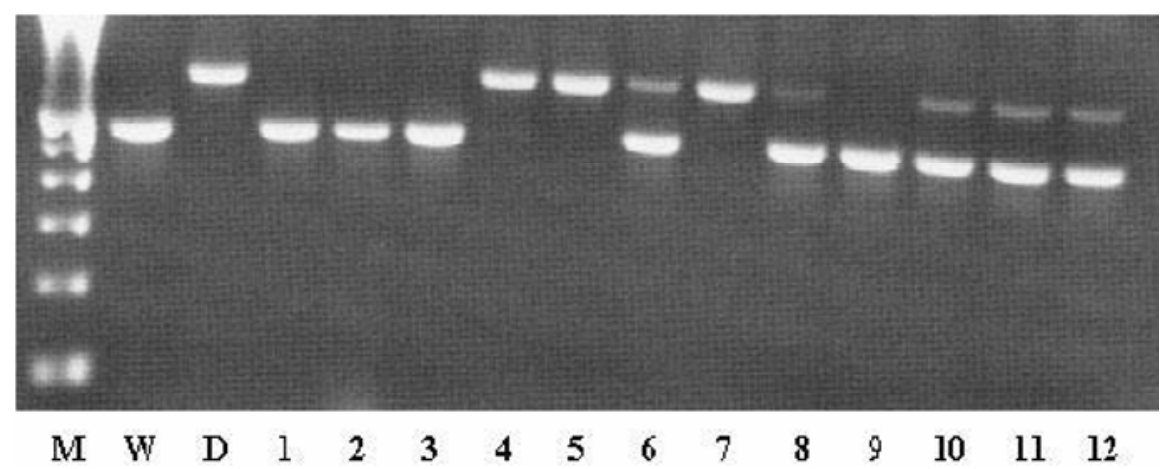

Fig. 4. Segregation of the sequence characterized amplified region (SCAR) marker BN204 linked to resistance against Leptosphaeria maculans PG3 in $\mathrm{F}_{2}$ 'Westar' $\times$ 'Dunkeld' progeny. M: 100-bp ladder, W: 'Westar', D: 'Dunkeld', and 1 to 12: $\mathrm{F}_{2}$ 'Westar' $\times$ 'Dunkeld' progeny. 1 to 3 and 9 represent homozygotic susceptible progeny; 4,5 , and 7 are homozygotic resistant progeny; and 6, 8, and 10 to 12 are heterozygotic resistant progeny. of resistance, NA12A02-200, and $\mathrm{BN} 204$ respectively, were lower than the critical value $\left(\chi_{(1,0.05)}^{2}=3.84\right)$.

\section{DISCUSSION}

The screening of the University of Manitoba Brassica germplasm revealed that sources of canola resistance against blackleg caused by $L$. maculans PG3 were available in two $B$. napus and two $B$. juncea cultivars. We selected 'Dunkeld' for further analysis because, being a spring type, it is easier to manipulate than the winter cultivar Quinta and B. juncea 'Cutlass' and 'Domo' in crossing with B. napus spring cultivars, such as 'Westar', and with commercial varieties for genetic studies and gene pyramiding. The resistance in 'Dunkeld' against blackleg is thought to be polygenic in part and can be traced back to possible sources present in its pedigree such as B. napus 'Chikuzen' and 'Norin' and B. juncea BJ168 (21,32). Our resistance screening experiment revealed that 'Dunkeld' was resistant against L. maculans PG3 but was susceptible to PG2 and PG4. The results suggest the presence of at least one major resistance gene in addition to polygenic resistance. These results also support the supposition that the decline of 'Dunkeld' blackleg resistance and reduction in grain yields recorded in Australia from 1999 to 2001 were due to a change in virulence in the blackleg pathogen (21). As the three pathogenicity groups coexist in Australia (7), the change in virulence may have resulted from the pathogen population composition shifting to higher proportions of PG2 and PG4 after the release of 'Dunkeld'. The conclusion that a major

16.4

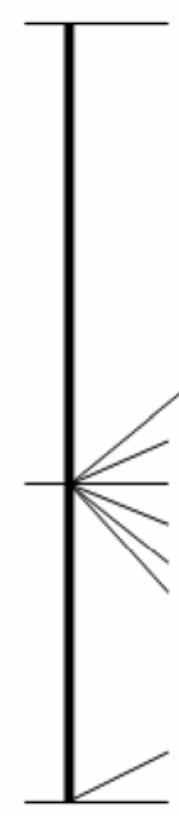

$\mathrm{BG}_{18} \mathrm{ODD}_{20-480}$

$\mathrm{NA}_{12} \mathrm{~A}_{02-200}$

$\mathrm{NA}_{12} \mathrm{~A}_{02-190}$

$\mathrm{BG}_{20} \mathrm{SA}_{12480}$

$\mathrm{BG}_{20} \mathrm{SA}_{12475}$

$\mathrm{BN}_{204}$

Rpg ${ }_{3}$ Dun

$\mathrm{BG}_{20} \mathrm{SA}_{12-465}$

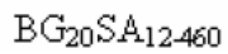

Fig. 5. Linkage group of 'Westar' $\times$ 'Dunkeld' population with marker loci linked to resistance gene against Leptosphaeria maculans PG3 from 'Dunkeld' ( $\mathrm{Rpg}_{3}$ Dun). Genetic distance values are expressed in $\mathrm{cM}$ units. 
gene $\left(\mathrm{Rpg}_{3} \mathrm{Dun}\right)$ is responsible for resistance in 'Dunkeld' against PG3 was supported by the resistance segregation ratio of 3:1 in $F_{2}$ 'Westar' × 'Dunkeld' progeny. $\mathrm{Rpg}_{3}$ Dun is likely similar to the Rlm4 gene, which was previously suggested to be the major resistance gene in 'Dunkeld' (50). $R \operatorname{lm} 4$ has also been located in a cluster of four other tightly linked genes including $R \operatorname{lm} 3, R \operatorname{lm} 7$, and $R \operatorname{lm} 9$ (17).

Molecular markers linked to the 'Dunkeld' resistance gene against L. maculans PG3 were identified with a combination of BSA and SRAP procedures. A linkage group with eight molecular markers linked to this resistance trait was identified. DNA sequencing and BLAST analysis of a sequence from one of these markers allowed us to physically locate this resistance gene on a BAC clone from $B$. rapa subsp. pekinensis. Analysis of the $B$. rapa subsp. pekinensis genomic region close to the homologs of markers in 'Dunkeld' linked to $R p g_{3}$ Dun revealed that it contains open reading frames producing different putative transcripts that could be alternatively expressed in different stress conditions $(9,38)$. Results from linkage mapping and sequence analysis also suggested that the 'Dunkeld' resistance trait against $L$. maculans PG3 might be associated with a gene encoding protein kinase. Protein kinases have several functions including defense responses (22). Plant serine/threonine kinases and kinase receptors involved in disease resistance have been reported in crops such as barley, tomato, and rice $(12,30,31,41)$. Further studies will help us understand the functions and expression mechanisms of the serine/threonine ste-20 kinase encoding genes in B. napus as well as their role in compatible and incompatible interactions between canola and L. maculans. The SCAR marker BN204 linked to $\mathrm{Rpg}_{3}$ Dun resistance gene can be used in marker-assisted selection of canola resistance against blackleg caused by L. maculans PG3.

\section{ACKNOWLEDGMENTS}

This project was funded by Alberta Agriculture, Food and Rural Development Council, Manitoba Rural Adaptation Council, and Saskatchewan Council for Community Development through the MRAC/CARD Program.

\section{LITERATURE CITED}

1. Aljanabi, S. M., and Martinez, I. 1997. Universal and rapid salt-extraction of high quality genomic DNA for PCR-based techniques. Nucleic Acids Res. 25:4692-4693.

2. Altschul, S. F., Gish, W., Miller, W., Myers, E. W., and Lipman, D. J. 1990. Basic local alignment search tool. J. Mol. Biol. 215:403410 .

3. Ananga, A. O., Cebert, E., Soliman, K., Kantey, R., Pacumbaba, R. P., and Konan, K. 2006. RAPD markers associated with resistance to blackleg disease in Brassica species. Afr. J. Biotechnol. 5:2041-2048.

4. Ansan-Melayah, D., Balesdent, M. H., Buée, M., and Rouxel, T. 1995. Genetic characterization of AvrLm1, the first avirulence gene of Leptosphaeria maculans. Phytopathology
85:1525-1529.

5. Ansan-Melayah, D., Balesdent, M. H., Delourme, R., Pilet, M. L., Tanguy, X., Renard, M., and Rouxel, T. 1998. Genes for racespecific resistance against blackleg disease in Brassica napus L. Plant Breed. 117:373-378.

6. Balesdent, M. H., Attard, A., Kuhn, M. L., and Rouxel, T. 2002. Avirulence genes in the phytopathogenic fungus Leptosphaeria maculans. Phytopathology 92:1122-1133.

7. Balesdent, M. H., Barbetti, M. J., Li, H., Sivasithamparam, K., Gout, L., and Rouxel, T. 2005. Analysis of Leptosphaeria maculans race structure in a worldwide collection of isolates. Phytopathology 95:1061-1071.

8. Bansal, V. K., Kharbanda, P. D., Stringam, G. R., Thiagarajah, M. R., and Tewari, J. P. 1994. A comparison of greenhouse and field screening methods for blackleg resistance in double haploid lines of Brassica napus. Plant Dis. 78:276-281.

9. Bassett, C. L., Nickerso, M. L., Farell, R. E., Jr., and Harrison, M. 2004. Multiple transcripts of a gene for a leucine-rich repeat receptor kinase from morning glory (Ipomea nil) originate from different TATA boxes in a tissuespecific manner. Mol. Gen. Genomics 271:752-760.

10. Bonham, S., Staal, J., Thomma, B., Wang, M. L., and Dixelius, C. 2004. Characterization of an Arabidopsis-Leptosphaeria maculans pathosystem: Resistance partially requires camalexin biosynthesis and is independent of salicylic acid, ethylene, and jasmonic acid signaling. Plant J. 37:9-20.

11. Bradley, C. A., Parks, P. S., Chen, Y., and Fernado, W. G. D. 2005. First report of pathogenicity groups 3 and 4 of Leptosphaeria maculans on canola in North Dakota. Plant Dis. 89:776.

12. Brueggeman, R., Drader, T., and Kleinholfs, A. 2006. The barley serine/threonine kinase gene $\mathrm{RPg} 1$ providing resistance to stem rust belongs to a gene family with five other members encoding kinase domains. Theor. Appl. Genet. 113:1147-1158.

13. Chen, Y., and Fernando, W. G. D. 2005. First report of canola blackleg caused by pathogenicity group 4 of Leptosphaeria maculans in Manitoba. Plant Dis. 89:339.

14. Chen, Y., and Fernando, W. G. D. 2006. Prevalence of pathogenicity groups of Leptosphaeria maculans in Western Canada and North Dakota, USA. Can. J. Plant Pathol. 28:533539.

15. Chèvre, A. M., Eber, F., This, P., Barret, P., Tanguy, X., Brun, H., Delseny, M., and Renard, M. 1996. Characterization of Brassica nigra chromosomes and of blackleg resistance in $B$. napus- $B$. nigra addition lines. Plant Breed. 115:113-118.

16. Crouch, J. H., Lewis, B. G., and Mithen, R. F. 1994. The effect of a genome substitution on the resistance of Brassica napus to infection by Leptosphaeria maculans. Plant Breed. 112:265-278.

17. Delourme, R., Pilet-Nayel, M. L., Archipiano, M., Horvais, R., Tangy, X., Rouxel, T., Brun, H., Renard, M., and Badesdent, M. H. 2004. A cluster of major specific resistance genes to Leptosphaeria maculans in Brassica napus. Phytopathology 94:578-583.

18. Dion, Y., Gugel, R. K., Rakow, G. F. W., Seguin-Swartz, G., and, Landry, B. S. 1995. RFLP mapping of resistance to the blackleg disease [causal agent, Leptosphaeria maculans (Desm.) Ces. et de Not] in canola (Brassica napus). Theor. Appl. Genet. 91:1190-1194.

19. Fernando, W. G. D., and Chen, Y. 2003. First report on the presence of Leptosphaeria maculans pathogenicity group-3, the causal agent of blackleg of canola in Manitoba. Plant Dis. 87:1268.

20. Ferreira, M. E., Rimmer, S. R., Williams, P. H., and Osborn, T. C. 1995. Mapping loci controlling Brassica napus resistance to Leptosphaeria maculans under different screening conditions. Phytopathology 85:213-217.

21. Gororo, N., Salisbury, P., and Marcroft, S. 2004. Dunkeld and Rainbow: A tale of two Victorian canola varieties. Proc Int. Crop Sci. Congr. 4th, Brisbane, Australia, Sept. 26-Oct. 1, 2004. http://www.cropscience.org.au/icsc 2004/poster/3/7/3/975_gororo. htm.

22. Hardie, D. G. 1999. Plant protein serine/threonine kinases: Classification and functions. Annu. Rev. Plant Physiol. Plant Mol. Biol. 50:97-131.

23. Koch, E., Song, K., Osborn, T. C., and Williams, P. H. 1991. Relationship between pathogenicity and phylogeny based on restriction fragment length polymorphism in Leptosphaeria maculans. Mol. Plant-Microbe Interact. 4:341-349.

24. Kutcher, H. R., Van den Berg, C. G. J., and Rimmer, S. R. 1992. Variation in pathogenicity of Leptosphaeria maculans on Brassica spp. based on cotyledon and stem reactions. Can. J. Plant Pathol. 15:253-258.

25. Lander, E., Green, P., Abrahamson, J., Barlow, A., Daley, M., Lincoln, S., and Newburg, L. 1987. MAPMAKER: An interactive computer package for constructing primary genetic linkage maps of experimental and natural populations. Genomics 1:174-181.

26. Li, C. X., and Cowling, W. A. 2003. Identification of a single dominant allele for resistance to blackleg in Brassica napus Surpass 400 . Plant Breed. 122:485-488

27. Li, H., Barbetti, M. J., and Sivasithamparam, K. 2005. Hazard from reliance on cruciferous hosts as sources of major gene-based resistance for managing blackleg (Leptosphaeria maculans) disease. Field Crops Res. 91:185198.

28. Li, G., and Quiros, C. F. 2001. Sequencerelated amplified polymorphism (SRAP), a new system based on a simple PCR reaction: Its application to mapping and gene tagging in Brassica. Theor. Appl. Genet. 103:455-461.

29. Lincoln, S., Daly, M., and Lander, E. 1992. Constructing genetic maps with MAPMAKER/EXP 3.0. Whitehead Institute Technical Report. 3rd ed. Available online.

30. Liu, G.-Z., Pi, L.-Y., Walker, C. J., Ronald, P. C., and Song, W.-Y. 2002. Biochemical characterization of the kinase domain of the rice disease resistance receptor-like kinase XA21. J. Biol. Chem. 277:20264-20269.

31. Loh, Y.-T., and Martin, G. B. 1995. The Pto bacterial resistance gene and the Fen insecticide sensitivity gene encode functional protein kinases with serine/threonine specificity. Plant Physiol 108:1735-1739.

32. Mailer, R. J., Wratten, N., and Vonarx, M 1997. Genetic diversity amongst Australian canola varieties determined by random amplified polymorphic DNA. Aust. J. Exp. Agric. 37:793-800.

33. Mayerhofer, R., Bansal, V. K., Thiagarajah, M. R., Stringam, G. R., and Good, A. G. 1997. Molecular mapping of resistance to Leptosphaeria maculans in Australian varieties of Brassica napus. Genome 40:294-301.

34. Mayerhofer, R., Wilde, K., Mayerhofer, M. Lydiate, D., Bansal, V. K., Good, A. G., and Parkin, I. A. P. 2005. Complexities of chromosome landing in a high duplicated genome: Toward map-based cloning of a gene controlling blackleg resistance in Brassica napus. Genetics 171:1977-1988.

35. McNabb, W. M., Van Den Berg, C. G. J., and Rimmer, S. R. 1993. Comparison of inoculation methods for selection of plant resistance to Leptosphaeria maculans in Brassica napus. Can. J. Plant Sci. 73:1199-1207.

36. Mengistu, A., Rimmer, S. R., Koch, E., and Williams, P. H. 1991. Pathogenicity grouping 
of isolates of Leptosphaeria maculans on Brassica napus varieties and their disease reaction profiles on rapid-cycling brassicas. Plant Dis. 75:1279-1282.

37. Michelmore, R. W., Paran, I., and Kesseli, R. V. 1991. Identification of markers linked to disease-resistance genes by bulked segregant analysis: A rapid method to detect markers in specific genomic regions by using segregating populations. Proc. Natl. Acad. Sci. USA 88:9828-9832.

38. Narusaka, Y., Narusaka, M., Seki, M., Umezawa, T., Ishida, J., Nakajima, M., Enju, A., and Shinozaki, K. 2004. Crosstalk in the responses to abiotic and biotic stresses in Arabidopsis: Analysis of gene expression in cytochrome $\mathrm{P} 450$ gene superfamily by cDNA microarray. Plant Mol. Biol. 55:327-342.

39. Newman, P. L., and Bailey, D. J. 1987. Screening for resistance to canker (Leptosphaeria maculans) in winter oilseed rape (Brassica napus spp. oleifera). Plant Pathol. 36:346-354.

40. Nicholas, K. B., Nicholas, H. B., Jr., and Deerfield, D. W., II. 1997. GeneDoc: Analysis and Visualization of Genetic Variation, EMBNEW. NEWS 4:14.

41. Nirmala, J., Brueggerman, R., Maier, C., Clay, C., Rostoks, N., Kannangara, C. G., von Wettstein, D., Steffenson, B. J., and Kleinhofs, A. 2006. Subcellular localization and functions of barley stem rust resistance receptor-like serine/threonine-specific protein kinase Rpg1. Proc. Natl. Acad. Sci. USA 103:7518-7523.

42. Pang, E. C. K., and Halloran, G. M. 1996. The genetics of adult-plant blackleg (Leptosphaeria maculans) resistance from Brassica juncea in B. napus. Theor. Appl. Genet. 92:382-387.

43. Parkin, I. A., Sharpe, A. G., Keith, D. J., and Lydiate, D. J. 1995. Identification of the A and
C genomes of the amphidiploid Brassica napus (oilseed rape). Genome 38:1122-1131.

44. Pongam, P., Osborn, T. C., and Williams, P. H. 1998. Genetic analysis and identification of amplified fragment length polymorphism marker linked to alm1 avirulence gene of Leptosphaeria maculans.

Phytopathology 88:1068-1072.

45. Rimmer, S. R. 2006. Resistance genes to Leptosphaeria maculans in Brassica napus. Can. J. Plant Pathol. 28:S288-S297.

46. Rimmer, S. R., Borhan, M. H., Zhu, B., and Somers, D. 1999. Mapping resistance genes in Brassica napus to Leptosphaeria maculans. Proc. Int. Rapeseed Congr., 10th, Canberra, Australia. p. 262.

47. Rimmer, S. R., and Van den Berg, C. G. J. 1992. Resistance of oilseed Brassica spp. to blackleg caused by Leptosphaeria maculans. Can. J. Plant Pathol. 14:56-66.

48. Rouxel, T., and Balesdent, M. H. 2005. The stem canker (blackleg) fungus, Leptosphaeria maculans, enters the genomic era. Mol. Plant Pathol. 6:225-241.

49. Rouxel, T., Mendes-Pereira, E., Brun, H., and Balesdent, M. H. 2004. Species complex of fungal phytopathogens: The Leptosphaeria maculans-L. biglobosa case study. In plant Genome: Biodiversity and Evolution, vol. 2: Lower Groups. A. K. Sharma and A. Sharma, eds. Science Publishers, Inc., Enfield, NH. pp. 33-75.

50. Rouxel, T., Wilner, E., Coudard, L., and Balesdent, M. H. 2003. Screening and identification of resistance to Leptosphaeria maculans (stem canker) in Brassica napus accessions. Euphytica 133:219-231.

51. Roy, N. N. 1984. Interspecific transfer of Brassica juncea-type high blackleg resistance to Brassica napus. Euphytica 33:295-303.

52. Saal, B., Brun, H., Glais, I., and Stuss, D. 2004. Identification of a Brassica junceaderived recessive gene conferring resistance to Leptosphaeria maculans in oilseed rape. Plant Breed. 123:505-511.

53. Shoemaker, R. A., and Brun, H. 2001. The teleomorph of the weakly aggressive segregate of Leptosphaeria maculans. Can. J. Bot. 79:412-419.

54. Sjödin, C., and Glimelius, K. 1988. Screening for resistance to Phoma lingam (Tode ex Fr. Desm within Brassicaceae. J. Plant Pathol 1233:322-332.

55. Thompson, J. D., Gibson, T. J., Plewniak, F. Jeanmougin, F., and Higgins, D. G. 1997. The ClustalX windows interface: Flexible strategies for multiple sequence alignment aided by quality analysis tools. Nucleic Acids Res 24:4876-4882.

56. West, J. C., Kharbanada, P. D., Barbetti, M. J and Fitt, B. D. L. 2001. Epidemiology and management of Leptosphaeria (Phoma stem canker) on oilseed rape in Australia, Canada, and Europe. Plant Pathol. 50:10-27.

57. Williams, P. H. 1985. Crucifer Genetic Cooperatives (CrGC) resource book. University of Wisconsin, Madison, WI.

58. Williams, P. H. 1992. Biology of Leptosphaeria maculans. Can. J. Plant Pathol. 14:30-35.

59. Williams, R. H., and Fitt, B. D. L. 1999. Differentiating A and B groups of Leptosphaeria maculans, causal agent of stem canker (blackleg) of oilseed rape. Plant Pathol. 48:161-175.

60. Yu, F., Lydiate, D. J., and Rimmer, S. R. 2005. Identification of two novel genes for blackleg resistance in Brassica napus. Theor. Appl. Genet. 110:969-979. 